\title{
Association of genetic variants of the histamine H1 and muscarinic $M 3$ receptors with $B M I$ and HbA1c values in patients on antipsychotic medication
}

\author{
Jelle Vehof • Arne J. Risselada • Asmar F. Y. Al Hadithy • Huibert Burger • \\ Harold Snieder • Bob Wilffert • Johan Arends • Lex Wunderink • \\ Henrikus Knegtering • Durk Wiersma • Dan Cohen • Hans Mulder • \\ Richard Bruggeman
}

Received: 20 October 2010 / Accepted: 27 January 2011 /Published online: 19 February 2011

(C) The Author(s) 2011. This article is published with open access at Springerlink.com

\begin{abstract}
Rationale Antipsychotic affinity for the histamine $\mathrm{H} 1$ receptor and the muscarinic M3 receptor have been associated with the side effects weight gain, and development of diabetes, respectively.

Objectives We investigated polymorphisms of the histamine $\mathrm{H} 1$ (HRH1) and muscarinic acetylcholine receptor M3 (CHRM3) receptor genes for an association with body mass index (BMI) and glycated hemoglobin (HbAlc).

Methods We included 430 Caucasian patients with a nonaffective psychotic disorder using antipsychotics for at least 3 months. Primary endpoints of the study were cross-
\end{abstract}

Electronic supplementary material The online version of this article (doi:10.1007/s00213-011-2211-x) contains supplementary material, which is available to authorized users.

J. Vehof $(\bowtie) \cdot$ H. Burger $\cdot$ D. Wiersma $\cdot$ R. Bruggeman Department of Psychiatry, University Medical Center Groningen, University of Groningen,

Groningen, The Netherlands

e-mail: j.vehof@epi.umcg.nl

J. Vehof $\cdot$ H. Burger $\cdot$ H. Snieder

Department of Epidemiology,

University Medical Center Groningen, University of Groningen,

Groningen, The Netherlands

A. J. Risselada $\cdot$ H. Mulder

Department of Clinical Pharmacy, Wilhelmina Hospital Assen,

Assen, The Netherlands

\section{A. J. Risselada $\cdot$ H. Mulder}

Department of Pharmacoepidemiology and Pharmacotherapy,

Utrecht Institute for Pharmaceutical Sciences (UIPS),

Utrecht University,

Utrecht, The Netherlands sectionally measured BMI and $\mathrm{HbAlc}$; secondary endpoints were obesity and hyperglycaemia. Two singlenucleotide polymorphisms (SNPs) in the HRH1 gene, rs346074 and rs346070, and one SNP in the CHRM3 gene, rs3738435, were genotyped. Our primary hypothesis in this study was an interaction between genotype on BMI and antipsychotic affinity for the $\mathrm{H} 1$ and $\mathrm{M} 3$ receptor.

Results A significant association of interaction between haplotype rs346074-rs346070 and BMI ( $p$ value 0.025 ) and obesity ( $p$ value 0.005 ) in patients using high-H1 affinity antipsychotics versus patients using low-H1 affinity antipsychotics was found. There was no association of

A. F. Y. Al Hadithy · B. Wilffert · R. Bruggeman

Department of Pharmacotherapy and Pharmaceutical Care,

University of Groningen,

Groningen, The Netherlands

A. F. Y. Al Hadithy

Hospital Pharmacy, Erasmus University Medical Center,

Rotterdam, The Netherlands

\section{J. Arends}

Mental Health Services Drenthe,

Assen, The Netherlands

L. Wunderink

Mental Health Services Friesland,

Leeuwarden, The Netherlands

H. Knegtering

Mental Health Services Lentis,

Groningen, The Netherlands

D. Cohen

Mental Health Services GGZ-NHN,

Heerhugowaard, The Netherlands 
CHRM3 gene variant rs3738435 with BMI, and we observed no association with $\mathrm{HbA} 1 \mathrm{c}$ or hyperglycaemia in any of the variants.

Conclusions This study, for the first time, demonstrates a significant association between $H R H 1$ variants and BMI in patients with a psychotic disorder using antipsychotics. In future, genotyping of $H R H 1$ variants may help predicting weight gain in patients using antipsychotics.

Keywords Antipsychotics $\cdot \mathrm{BMI} \cdot \mathrm{HbA1c} \cdot$ Schizophrenia Polymorphism $\cdot$ Histamine $\cdot$ Muscarine $\cdot$ Pharmacogenetics . Weight gain $\cdot$ Hyperglycaemia

\section{Introduction}

The majority of patients with schizophrenia or other psychotic disorder use antipsychotic medication. Antipsychotic treatment, especially the use of clozapine and olanzapine, increases the risk of developing obesity (Allison et al. 1999; Lieberman et al. 2005; Parsons et al. 2009) and type 2 diabetes mellitus (T2DM) (Leslie and Rosenheck. 2004; Holt et al. 2005; Lieberman et al. 2005; Miller et al. 2005b; Newcomer. 2005; Gianfrancesco et al. 2006; Nasrallah. 2006). The underlying mechanisms of antipsychotic-induced weight gain and diabetes mellitus are unknown, and may involve different pathways. As in the general population, obesity may have an unfavorable impact on glucose homeostasis in patients using antipsychotics. However, several studies have shown elevated serum insulin levels following atypical antipsychotic medication independent of body mass index (BMI) (Melkersson et al. 2000; Arranz et al. 2004; Henderson et al. 2005). This finding suggests that antipsychotics may directly affect glucose homeostasis by mechanisms other than by weight gain alone. There is also a considerable variability among users of the same antipsychotic in weight gain and T2DM (e.g., not all patients on clozapine ultimately develop T2DM). It is plausible that this variability in patient propensity to these side effects is determined by a combination of genetic and environmental factors.

Atypical antipsychotics may differ highly in their affinities for the dopaminergic, serotonergic, histaminergic, adrenergic, and muscarinic acetylcholine receptors (Roth et al. 2004). Combining receptor affinities and clinical data, several authors have concluded that histamine H1 antagonism showed the best correlation with drug-induced weight gain and diabetes mellitus (Wirshing et al. 1999; Kroeze et al. 2003; Matsui-Sakata et al. 2005). Likewise, antagonism of the muscarine acetylcholine receptor was suggested to play an important role, especially in the development of diabetes mellitus (Matsui-Sakata et al. 2005; Silvestre and Prous. 2005). Interactions with serotonergic (5-HT2C and
5-HT6) and adrenergic (alpha1A) receptors were also significantly correlated with metabolic parameters (Kroeze et al. 2003; Matsui-Sakata et al. 2005). To date, pharmacogenetic studies have shown the most consistent evidence for polymorphisms in the 5-HT2C receptor and leptin genes to be associated with antipsychotic-induced weight gain (Reynolds et al. 2003; Ellingrod et al. 2005; Miller et al. 2005a; Templeman et al. 2005; Zhang et al. 2007; Kang et al. 2008; Gregoor et al. 2009) and the metabolic syndrome (Mulder et al. 2007a; Yevtushenko et al. 2008; Mulder et al. 2009; Risselada et al. 2010). So far, only two studies (Basile et al. 2001; Hong et al. 2002) have reported on histamine $\mathrm{H} 1$ polymorphisms and antipsychotic-induced weight gain, both finding no association. Thus, the contribution of genetic variations of the histamine and muscarine acetylcholine receptors on the emergence of weight gain and diabetes in antipsychotic-treated patients remains to be elucidated.

The ventromedial hypothalamus and the paraventricular nucleus of the brain, where $\mathrm{H} 1$ receptors are localized in high density (Sakata et al. 1995), play a central role in the development of obesity by regulating energy expenditure and food intake (Masaki et al. 2004). Clozapine, olanzapine, and quetiapine exhibit the highest affinities for the $\mathrm{H} 1$ receptor, whereas risperidone and aripiprazole exhibit lower, and ziprasidone and haloperidol exhibit hardly any affinity towards the H1 receptor (Roth et al. 2004; Nasrallah. 2008). Clozapine and olanzapine are also known to induce most weight gain, followed by quetiapine and risperidone. Aripiprazole, ziprasidone, and haloperidol are known to cause little or no weight gain at all (Wirshing et al. 1999; Nasrallah. 2008). Tricyclic antidepressants with a high antihistaminergic effect (e.g. amitriptyline) are found to induce weight gain as well (Zimmermann et al. 2003). The histamine $\mathrm{H} 1$ receptor may therefore play a role in the etiology of medication-induced weight gain.

The M3 receptor is expressed on pancreatic $\beta$ cells. These receptors seem to play a critical role in regulating insulin release and glucose homeostasis (Gautam et al. 2006). Impaired glucose tolerance and reduced levels of insulin were found in mice with targeted deletions in the CHRM3 gene (Gautam et al. 2006). This might indicate that antagonism of the $\beta$-cell M3 receptor leads to a higher risk of hyperglycemia and developing diabetes in humans. Olanzapine and clozapine, which have the highest binding affinities with the M3 receptor, have been associated with highest risk of developing T2DM (Citrome et al. 2004; Leslie and Rosenheck. 2004; Holt et al. 2005; Newcomer. 2005) and higher levels of glycated hemoglobin (HBA1c) and blood glucose (Lieberman et al. 2005; Gianfrancesco et al. 2006; Nasrallah. 2008). Risperidone, quetiapine, ziprasidone, haloperidol, and aripiprazole have weak to absent M3 receptor antagonistic activity (Roth et al. 2004; 
Nasrallah. 2008) and are associated with lower levels of HbA1c and blood glucose in patients (Lieberman et al. 2005; Nasrallah. 2008).

Out of the known $\mathrm{H} 1$ receptor gene $(H R H 1)$ splice variants, we studied two polymorphisms in the $\mathrm{B} / \mathrm{K}$ variant, which is by far the most prevalent $(95 \%)$ in the brain (Swan et al. 2006). Rs346070 is a single-nucleotide polymorphism (SNP) and may be functional as it is located in the exonic splicing enhancer region. SNP rs346074 is located in the transcription factor binding sites of the HRH1 gene and may thus affect transcription rates. The muscarinic acetylcholine receptor M3 (CHRM3) variant rs3738435 is located in the $5^{\prime}$ untranslated region of the first exon. Its $\mathrm{C}$ allele was found to be associated with increased risk of earlyonset type 2 diabetes and a reduced acute insulin response in a family-based sample of Pima Indians (Guo et al. 2006).

This is, as far as we know, the first study to examine the pharmacogenetics of genetic variations in genes encoding for the histamine H1 (rs346074 and rs346070) and muscarine M3 receptors (rs3738435) in relation to BMI and $\mathrm{HbAlc}$ in Caucasian psychosis patients using antipsychotics. Our primary hypothesis in this cross-sectional study is an interaction between the mentioned variations on BMI and antipsychotic affinity for the $\mathrm{H} 1$ and $\mathrm{M} 3$ receptor.

\section{Materials and methods}

Setting

For this study, three similar psychiatric patient populations from the Netherlands were pooled. The majority of patients were from the ongoing 'Pharmacotherapy Monitoring and Outcome Survey' (PHAMOUS). PHAMOUS is an initiative from the Rob Giel Research centre, including three Mental Health Care Institutions and the University Centre of Psychiatry of Groningen. It combines a yearly somatic screening with routine outcome assessment in patients using antipsychotics included. Subjects included in this study originated from the northern part of the Netherlands. The two other study populations have been described in detail elsewhere (Cohen et al. 2006; Mulder et al. 2007a; Mulder et al. 2009). In brief, these populations consisted of patients from a Department of Psychiatric Disorders of a general hospital in the North of the Netherlands (Mulder et al. 2007a; Mulder et al. 2009), and patients from a Mental Health Care Organisation in the West of the Netherlands (Cohen et al. 2006).

Design and patients

A cross-sectional design was used to assess the association between the variants with BMI and $\mathrm{HbAlc}$. Caucasian patients (northern European ancestry) were eligible for inclusion in this study when they met Diagnostic and Statistical Manual of Mental Disorders, Fourth Edition (DSM-IV) criteria for a non-affective psychotic disorder (schizophrenia, schizophreniform disorder, schizoaffective disorder, delusional disorder, psychotic disorder not otherwise specified (NOS)), were 18 years or older, and used one or more antipsychotics for at least 3 months.

\section{Outcome measures}

The primary endpoints of the study were BMI, calculated as body weight (kilogram) divided by height squared (square meter), and the proportion glycated hemoglobin HbAlc (percent). BMI was measured in all patients; HbA1c values were available only in the PHAMOUS population.

\section{Determinants}

Primary determinants were the genotypes of the two SNPs in the HRH1 gene, rs346074 (G/A) and rs346070 (C/T), and one SNP in the CHRM3 gene, rs3738435 (C/T). Other clinical and demographic (co)variables that were measured in the study were gender, age, patient population, DSM-IVdiagnosis, and antipsychotic medication used at the day of assessment.

\section{Genotyping}

The study protocol was approved by the local university hospital medical ethics committee and all participants gave their written informed consent. Genomic DNA was extracted from EDTA whole blood according to standard protocols. Genotyping of rs3738435, rs346070, and rs346074 was conducted blind to the clinical status of the patients. Fluorogenic 5'-exonuclease TaqMan ${ }^{\circledR}$ assays were applied for the genotyping (Made-To-Order assays obtained from Applied Biosystems; C2747428510, C60474110, and C2685588510, respectively). Genotyping success rates were $99 \%$ for rs346074 and $100 \%$ for rs346070 and rs3738435.

\section{Statistical analysis}

To compare BMI and HbAlc values among various users of antipsychotics (i.e., BMI in users of clozapine versus olanzapine versus risperidon versus aripiprazole versus quetiapine versus users of more than one antipsychotic) and between patients using typical versus atypical antipsychotics we applied analysis of variance (ANOVA) and Student's $t$ test, respectively. We used linear regression to explore the relationship of BMI and $\mathrm{HbAlc}$ with the independent variables age, gender, and patient population. 
Table 1 Demographic, genetic, and unadjusted clinical variables of the total study sample

\begin{tabular}{|c|c|}
\hline Characteristic & Total study sample $(n=430)$ \\
\hline Age, mean (range) & $38.4(18-69)$ \\
\hline \multicolumn{2}{|l|}{ Gender } \\
\hline$\cdot$ Male & $290(67 \%)$ \\
\hline •Female & $140(33 \%)$ \\
\hline \multicolumn{2}{|l|}{ DSMIV-Diagnosis } \\
\hline •Schizophrenia & $333(77 \%)$ \\
\hline -Schizoaffective disorder & $77(18 \%)$ \\
\hline •Psychotic disorder NOS & $20(5 \%)$ \\
\hline \multicolumn{2}{|l|}{ Antipsychotic medication } \\
\hline •Typical & $68(16 \%)$ \\
\hline -Atypical & $362(84 \%)$ \\
\hline BMI $\left(\mathrm{kg} / \mathrm{m}^{2}\right)$, mean (SD) & $28.0(5.2)$ \\
\hline \multicolumn{2}{|l|}{ Weight category } \\
\hline •Non-obese $(\mathrm{BMI}<25)$ & $135(31 \%)$ \\
\hline • Overweight (BMI 25-30) & $157(37 \%)$ \\
\hline • Obesity $(\mathrm{BMI}>30)$ & $138(32 \%)$ \\
\hline \multicolumn{2}{|l|}{ HbA1c $(\%)(n=221)$} \\
\hline •Mean (SD) & $5.78(1.25)$ \\
\hline$\cdot$ Hyperglycaemia (HbA1c $\geq 6.1 \%$ or antidiabetic medication) & $30(14 \%)$ \\
\hline \multicolumn{2}{|l|}{ Genotype rates } \\
\hline •HRH1 rs346074 (GG/GA/AA) & $182 / 189 / 55$ \\
\hline •HRH1 rs346070 (CC/CT/TT) & $286 / 128 / 15$ \\
\hline •CHRM3 rs3738435 (TT/TC/CC) & $276 / 137 / 17$ \\
\hline
\end{tabular}

Departure from Hardy-Weinberg Equilibrium was calculated by a $\chi^{2}$ test with $1 \mathrm{df}$. We initially considered an additive model for rs346074 (HRH1), and, due to the low numbers of the recessive genotype, a dominant model for rs3738435 (CHRM3) and rs346070 (HRH1).

We first compared demographic characteristics between the genotypes of the three variants. To test our primary hypothesis, we applied linear regression to test whether genotype in users of high-affinity antipsychotics has a significantly different outcome on BMI and HbAlc than in users of low-affinity antipsychotics. We used the interaction term affinity $x$ genotype in our model to test this association, where affinity was coded as 1 or 0 when the patient used a high- or a low-affinity antipsychotic, respectively. A pKi $>7$ defined a high-affinity antipsychotic for a certain receptor (Nasrallah. 2008), the other antipsychotics were considered having a low affinity. We adjusted for age, gender, and patient population in our analyses. Similarly, logistic regression was used to analyze the associations with obesity (BMI $>30 \mathrm{~kg} / \mathrm{m}^{2}$ ) and hyperglycemia (HbAlc $\geq 6.1 \%$ or the use of antidiabetics). Additionally, for the two $H R H 1$ variants haplotype analysis using the haplotype trend regression approach (Zaykin et al. 2002) was performed, with haplotypes inferred by the software package PHASE (Stephens et al. 2001; Stephens and Donnelly. 2003). Pairwise linkage disequilibirum (LD) was tested by calculating $\mathrm{D}^{\prime}$, as well as $\mathrm{r}^{2}$. All of the analyses were performed using standard software (SPSS 16.0 for Windows). The level of significance was set at 0.05 , two-sided.

\section{Results}

Subjects

A total of 430 subjects met the inclusion criteria. Table 1 presents their demographic, genetic, and clinical characteristics. Approximately $95 \%$ of the patients had a diagnosis within the schizophrenia spectrum, the other patients had a psychotic disorder not otherwise specified (NOS).

\section{Medication}

Patients used monotherapy clozapine (21.9\%), olanzapine $(22.6 \%)$ or risperidon $(22.1 \%)$, aripiprazole $(2.3 \%)$, quetiapine (4.2\%), typical antipsychotics $(14.4 \%)$, or had a combination of more than one antipsychotic $(12.6 \%)$. No substantial differences in BMI (range 27.4-29.3 kg/m²) were found between users of the various antipsychotics ( $p$ value ANOVA 0.58) or between different diagnoses. HbA1c values (range 5.5-6.8\%) were significantly differ- 
ent between the various antipsychotics ( $p$ value ANOVA 0.033 ). Between users of typical and atypical antipsychotics, no differences in BMI and HbAlc were found ( $p$ value Student's $t$ test 0.93 and 0.82 , respectively). Of all antipsychotics used in our population, clozapine, olanzapine, and quetiapine were defined as high $\mathrm{H} 1$ receptor affinity antipsychotics, and clozapine and olanzapine as high M3 receptor affinity antipsychotics.

\section{Association analyses}

Genotype distributions were consistent with the HardyWeinberg equilibrium ( $p$ values $0.59,0.88$, and 1.00 for rs346074, rs346070, and rs3738435, respectively). Age (increase of $0.055 \mathrm{~kg} / \mathrm{m}^{2}$ per year, $p$ value 0.021 ) and gender (increase of $2.97 \mathrm{~kg} / \mathrm{m}^{2}$ if female, $p$ value $<0.001$ ) were significantly associated with BMI. Patient population was not associated with BMI. HbA1c was not associated with patient population, age, or gender. Demographic characteristics, DSM-IV-diagnosis, and antipsychotic distributions did not differ between genotype groups in all three variants.

In Table 2 the genetic associations with BMI and obesity are depicted. In users with antipsychotics with high $\mathrm{H} 1$ affinity, there was a non-significant increase in BMI per A allele of rs346074 and per $\mathrm{T}$ allele of rs346070. An opposite trend can be seen in users with a low $\mathrm{H} 1$ affinity antipsychotic (see Fig. 1). The increased trend in BMI with minor alleles of rs346074 and rs346070 in high H1 affinity antipsychotic users was significantly different from the decreased trend in BMI with minor alleles in low H1 affinity antipsychotic users. The interaction term genotype $\mathrm{x}$ affinity tested significant when using an additive or recessive model for the A allele of $\operatorname{rs} 346074$ ( $p$ values

Table 2 Mean BMI values and obesity proportions of genotype groups for SNPs rs346074, rs346070, and rs3738435 among 430 antipsychotic users

\begin{tabular}{|c|c|c|c|c|c|c|}
\hline \multirow{2}{*}{$\frac{\text { Variables }}{\text { HRHI rs346074 }}$} & \multirow{2}{*}{$\frac{\text { No. of patients }}{\text { GG/GA/AA }}$} & \multicolumn{3}{|c|}{ Mean (SD)/proportion } & \multirow[t]{2}{*}{$p$ value $\beta$ genotype } & \multirow[t]{2}{*}{$p$ value $\beta$ interaction genotype $\mathrm{x}$ affinity } \\
\hline & & GG & GA & $\mathrm{AA}$ & & \\
\hline BMI & $182 / 189 / 55$ & $28.0(5.2)$ & $27.8(5.3)$ & $28.5(5.0)$ & 0.93 & 0.046 \\
\hline High aff. & $83 / 97 / 28$ & $27.5(4.2)$ & $27.7(5.3)$ & $30.1(5.3)$ & 0.27 & \\
\hline Low aff. & $99 / 92 / 27$ & $28.4(5.9)$ & $27.9(5.2)$ & $26.8(4.0)$ & 0.10 & \\
\hline Obesity & $182 / 189 / 55$ & $34 \%$ & $30 \%$ & $31 \%$ & 0.58 & 0.005 \\
\hline High aff. & $83 / 97 / 28$ & $25 \%$ & $30 \%$ & $46 \%$ & 0.14 & \\
\hline Low aff. & $99 / 92 / 27$ & $40 \%$ & $30 \%$ & $15 \%$ & 0.015 & \\
\hline$H R H 1$ rs 346070 & $\mathrm{CC} / \mathrm{CT} / \mathrm{TT}$ & $\mathrm{CC}$ & $\mathrm{CT}$ & TT & & \\
\hline BMI & $286 / 128 / 15$ & $28.0(5.1)$ & $28.2(5.6)$ & $27.4(4.8)$ & 0.74 & 0.044 \\
\hline High aff. & $139 / 58 / 12$ & $27.6(4.7)$ & $29.0(5.9)$ & $28.5(4.2)$ & 0.10 & \\
\hline Low aff. & $147 / 70 / 3$ & $28.4(5.5)$ & $27.5(5.3)$ & $22.9(4.9)$ & 0.22 & \\
\hline Obesity & $286 / 128 / 15$ & $34 \%$ & $29 \%$ & $20 \%$ & 0.22 & 0.009 \\
\hline High aff. & $139 / 58 / 12$ & $28 \%$ & $38 \%$ & $25 \%$ & 0.36 & \\
\hline Low aff. & $147 / 70 / 3$ & $39 \%$ & $21 \%$ & $0 \%$ & 0.006 & \\
\hline CHRM3 rs3738435 & $\mathrm{TT} / \mathrm{TC} / \mathrm{CC}$ & $\mathrm{TT}$ & $\mathrm{TC}$ & $\mathrm{CC}$ & & \\
\hline BMI & $276 / 137 / 17$ & $28.0(5.2)$ & $27.6(5.2)$ & $30.4(5.5)$ & 0.60 & 0.88 \\
\hline High aff. & $127 / 57 / 7$ & $27.8(4.9)$ & $27.8(4.9)$ & $30.7(6.1)$ & 0.33 & \\
\hline Low aff. & $149 / 80 / 10$ & $28.3(5.5)$ & $27.5(5.4)$ & $30.2(5.3)$ & 0.90 & \\
\hline Obesity & $276 / 137 / 17$ & $31 \%$ & $32 \%$ & $53 \%$ & 0.15 & 0.56 \\
\hline High aff. & $127 / 57 / 7$ & $28 \%$ & $32 \%$ & $57 \%$ & 0.16 & \\
\hline Low aff. & $149 / 80 / 10$ & $34 \%$ & $33 \%$ & $50 \%$ & 0.56 & \\
\hline
\end{tabular}

BMI $\left(\mathrm{kg} / \mathrm{m}^{2}\right.$, mean and standard deviation) and obesity (\%) are given per genotype group, separated in users of antipsychotics with low and high affinity for the histamine $\mathrm{H} 1$ receptor (in rs346074 and rs346070 high affinity clozapine, olanzapine, and quetiapine) and the muscarine M3 receptor (in rs3738435 high affinity clozapine and olanzapine).

$p$ values are given for (1) the $\beta$ of the variable genotype in linear and logistic regression, and (2) the $\beta$ of the interaction term genotype $\mathrm{x}$ affinity in linear and logistic regression

All results are adjusted for age, gender, and population group

Genotype was tested additive in rs346074, and dominant for the minor allele in rs346070 and rs3738435

Significant $p$ values are shown in bold 

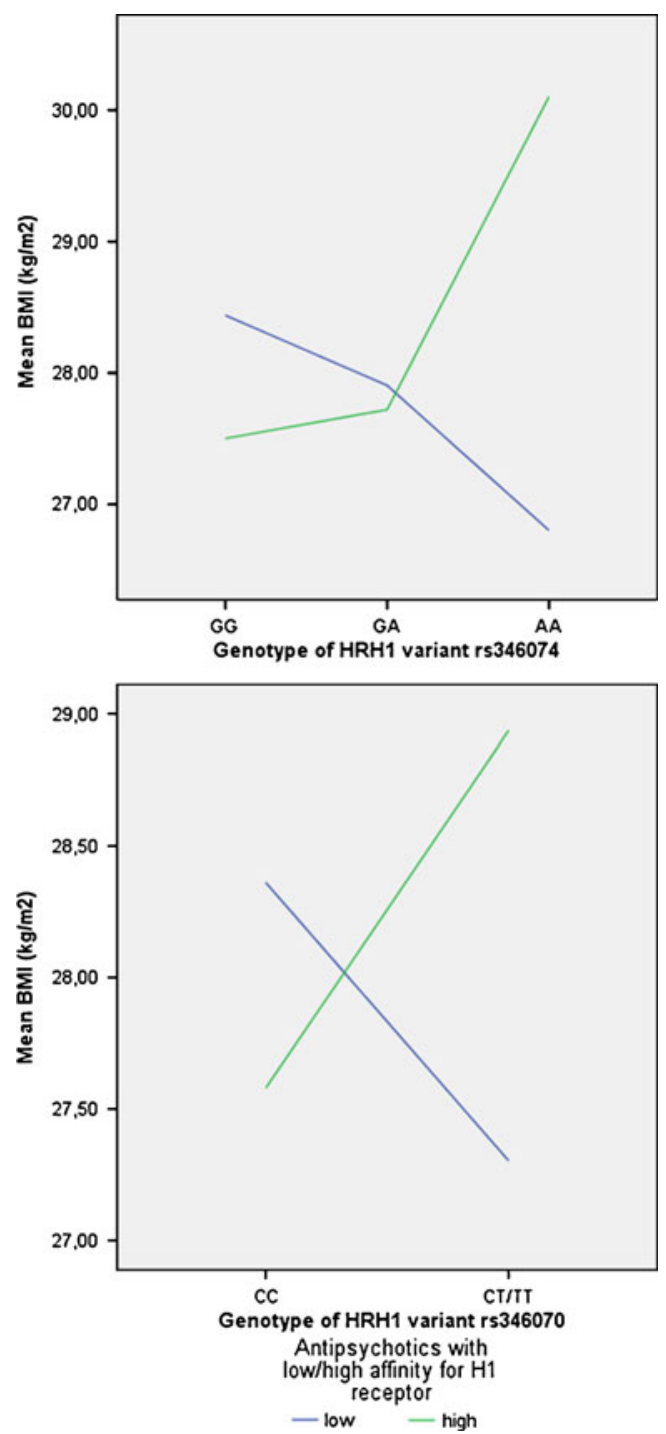

Fig. 1 HRHI variants rs346074 and rs346070 and mean BMI values in users of antipsychotics with and without affinity for the H1 receptor: a significant opposite effect can be seen between genotype and BMI in users of antipsychotics with high versus low affinity for the $\mathrm{H} 1$ receptor

0.046 and 0.033 , respectively), and when using a dominant model for the T allele of rs346070 ( $p$ value 0.044 ).

Logistic regression showed similar results regarding genotype and obesity, but even stronger and more significant. The interaction terms genotype $\mathrm{x}$ affinity for rs346074 (OR $2.80,95 \%$ CI 1.23-6.37, $p$ value 0.015 ) and rs346070 (OR $2.51,95 \%$ CI $1.33-4.74, p$ value 0.005 ) were both significant. Thus, for a patient, there is a more than twoand-a-half times higher risk of obesity per minor allele of rs346074 when having a high $\mathrm{H1}$ affinity antipsychotic as compared to when having a low H1 affinity antipsychotic.

The two HRHI SNPs were found to be in substantial LD $\left(\mathrm{D}^{\prime}=1.00, \mathrm{r}^{2}=0.42\right)$. Haplotype analyses of the two polymorphisms showed similar opposite effects of haplotype on
BMI and obesity in low and high $\mathrm{H} 1$ affinity antipsychotic users (see Table 3). For each AT-haplotype, having a high $\mathrm{H} 1$ affinity antipsychotic means a more than three times higher risk of obesity ( $p$ value 0.005 ) compared to the reference haplotype G-C, than when having a low H1 affinity antipsychotic.

In the total sample of antipsychotic users, CHRM3 rs3738435 had no effect on BMI. There were no differences in genotype effect on BMI between users of antipsychotics with high and low affinity for the M3 receptor. None of the three SNPs showed any association with HbA1c or hyperglycaemia (see supplemental Table 1).

\section{Discussion}

To the best of our knowledge, this is the first study to examine the pharmacogenetics of histamine H1 (rs346074 and rs346070) and muscarine M3 (rs3738435) receptor variants in relationship to weight gain and hyperglycaemia as proxied by BMI and $\mathrm{HbAlc}$ in Caucasian psychosis patients on antipsychotics. We demonstrated significant associations between the $H R H 1$ gene variants rs346070 and rs346074 and BMI in Caucasian patients with a psychotic disorder when comparing users of high $\mathrm{H} 1$ affinity antipsychotics with low $\mathrm{H} 1$ affinity antipsychotics. We found no association between the CHRM3 gene variant rs3738435 and BMI. We observed no association with $\mathrm{HbAlc}$ in any of the variants.

Although it has been proposed that histamine $\mathrm{H} 1$ receptor antagonism causes weight gain (Kroeze et al. 2003; MatsuiSakata et al. 2005), earlier studies on other histamine H1 receptor variants showed no relationship with clozapineinduced weight gain (Basile et al. 2001; Hong et al. 2002). Of note, post-hoc analysis in our study showed similar direction and effect size of the risk alleles on BMI in all three high H1 affinity antipsychotics studied (clozapine, olanzapine, and quetiapine), emphasizing the role of the histamine receptor.

Regarding the metabolic consequences of antipsychotic treatment, several receptors other than the $\mathrm{H} 1$ receptor are of importance (Reynolds and Kirk. 2010), especially the 5HT2C receptor. Previously, we have shown a significant association between 5-HT2C polymorphism rs1414334 and obesity (Mulder et al. 2007b) and the metabolic syndrome (Mulder et al. 2007a; Mulder et al. 2009; Risselada et al. 2010). The association with obesity of this polymorphism also tested significant in the present population (data not shown). We additionally included this polymorphism as a covariate in our regression analysis on obesity. This did not alter the results of the $\mathrm{H} 1$ polymorphisms on obesity, implying a 5-HT2C rs 1414334 independent, additive effect of our $\mathrm{H} 1$ polymorphisms.

Within the hypothalamus, histamine and the $\mathrm{H} 1$ receptor are part of the leptin-signaling pathway (Sakata et al. 1988; 


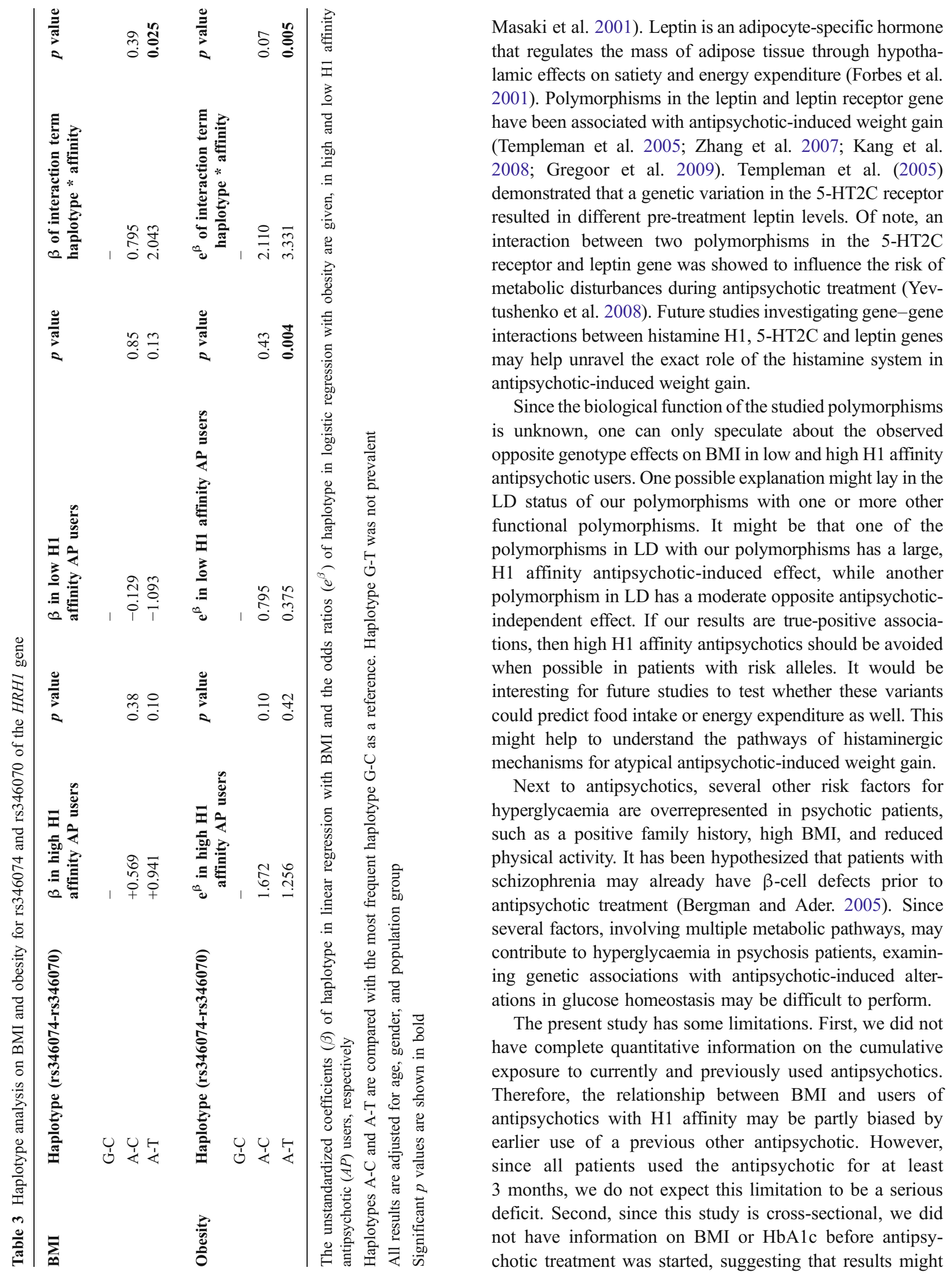


reflect non-antipsychotic-mediated pathways. However, this is very unlikely, since we decided to test the interaction between genotype and antipsychotic affinity for the certain receptor. We found significantly different genotype effects on BMI values between users of antipsychotics with high and low affinity for the H1 receptor. Since one would expect genotype effect on baseline BMI values to be similar between future users of low and high $\mathrm{H} 1$ affinity antipsychotics, non-antipsychotic-mediated effects of genotype would not lead to differences in genotype effect on BMI between users with high and low $\mathrm{H} 1$ affinity antipsychotics. Also, genotype distributions did not differ between users of low and high H1 affinity antipsychotics, ruling out the possibility of confounding by indication because of genotype. Despite its limitations this study has also several merits. First, compared to previous studies, we have a big sample size (more than 400 patients). Second, we have a very homogeneous group of Caucasian patients of Northern European ancestry, all diagnosed with a nonaffective psychosis.

In conclusion, the HRH1 gene haplotype consisting of rs346074 and rs346070 might be associated with BMI and obesity in patients using antipsychotics with high affinity for the histamine $\mathrm{H} 1$ receptor. These findings need to be replicated in independent samples. In none of the variants an association with $\mathrm{HbAlc}$ or hyperglycaemia was found. Genotyping for HRH1 variants may help predicting weight gain in patients using atypical antipsychotics. Further longitudinal studies are warranted to investigate the potential role on BMI of the HRH1 gene.

Acknowledgments The authors acknowledge the kind collaboration of patients and staff of the MHS Drenthe, MHS Friesland, MHS Lentis, MHS GGZ-NHN and UPC-UMCG, all in the Netherlands.

Conflict of interest The authors declare no conflict of interest, received no funding and grants, and declare no circumstances that could be perceived as a potential conflict of interest.

Open Access This article is distributed under the terms of the Creative Commons Attribution Noncommercial License which permits any noncommercial use, distribution, and reproduction in any medium, provided the original author(s) and source are credited.

\section{References}

Allison DB, Mentore JL, Heo M, Chandler LP, Cappelleri JC, Infante MC, Weiden PJ (1999) Antipsychotic-induced weight gain: a comprehensive research synthesis. Am J Psychiatr 156:16861696

Arranz B, Rosel P, Ramirez N, Duenas R, Fernandez P, Sanchez JM, Navarro MA, San L (2004) Insulin resistance and increased leptin concentrations in noncompliant schizophrenia patients but not in antipsychotic-naive first-episode schizophrenia patients. J Clin Psychiatr 65:1335-1342
Basile VS, Masellis M, McIntyre RS, Meltzer HY, Lieberman JA, Kennedy JL (2001) Genetic dissection of atypical antipsychoticinduced weight gain: novel preliminary data on the pharmacogenetic puzzle. J Clin Psychiatr 62(Suppl 23):45-66

Bergman RN, Ader M (2005) Atypical antipsychotics and glucose homeostasis. J Clin Psychiatr 66:504-514

Citrome L, Jaffe A, Levine J, Allingham B, Robinson J (2004) Relationship between antipsychotic medication treatment and new cases of diabetes among psychiatric inpatients. Psychiatr Serv 55:1006-1013. doi:10.1176/appi.ps.55.9.1006

Cohen D, Dekker JJ, Peen J, Gispen-de Wied CC (2006) Prevalence of diabetes mellitus in chronic schizophrenic inpatients in relation to long-term antipsychotic treatment. Eur Neuropsychopharmacol 16:187-194

Ellingrod VL, Perry PJ, Ringold JC, Lund BC, Bever-Stille K, Fleming F, Holman TL, Miller D (2005) Weight gain associated with the $759 \mathrm{C} / \mathrm{T}$ polymorphism of the $5 \mathrm{HT} 2 \mathrm{C}$ receptor and olanzapine. Am J Med Genet B Neuropsychiatr Genet 134B:76-78

Forbes S, Bui S, Robinson BR, Hochgeschwender U, Brennan MB (2001) Integrated control of appetite and fat metabolism by the leptin-proopiomelanocortin pathway. Proc Natl Acad Sci USA 98:4233-4237. doi:10.1073/pnas.071054298

Gautam D, Han SJ, Hamdan FF, Jeon J, Li B, Li JH, Cui Y, Mears D, Lu H, Deng C, Heard T, Wess J (2006) A critical role for beta cell M3 muscarinic acetylcholine receptors in regulating insulin release and blood glucose homeostasis in vivo. Cell Metab 3:449-461

Gianfrancesco F, Pesa J, Wang RH, Nasrallah H (2006) Assessment of antipsychotic-related risk of diabetes mellitus in a Medicaid psychosis population: sensitivity to study design. Am J Health Syst Pharm 63:431-441

Gregoor JG, van der Weide J, Mulder H, Cohen D, van Megen HJ, Egberts AC, Heerdink ER (2009) Polymorphisms of the LEPand LEPR gene and obesity in patients using antipsychotic medication. J Clin Psychopharmacol 29:21-25

Guo Y, Traurig M, Ma L, Kobes S, Harper I, Infante AM, Bogardus C, Baier LJ, Prochazka M (2006) CHRM3 gene variation is associated with decreased acute insulin secretion and increased risk for early-onset type 2 diabetes in Pima Indians. Diabetes 55:3625-3629

Henderson DC, Cagliero E, Copeland PM, Borba CP, Evins E, Hayden D, Weber MT, Anderson EJ, Allison DB, Daley TB, Schoenfeld D, Goff DC (2005) Glucose metabolism in patients with schizophrenia treated with atypical antipsychotic agents: a frequently sampled intravenous glucose tolerance test and minimal model analysis. Arch Gen Psychiatr 62:19-28. doi:10.1001/archpsyc.62.1.19

Holt RI, Bushe C, Citrome L (2005) Diabetes and schizophrenia 2005: are we any closer to understanding the link? J Psychopharmacol 19:56-65

Hong CJ, Lin CH, Yu YW, Chang SC, Wang SY, Tsai SJ (2002) Genetic variant of the histamine-1 receptor (glu349asp) and body weight change during clozapine treatment. Psychiatr Genet 12:169-171

Kang SG, Lee HJ, Park YM, Choi JE, Han C, Kim YK, Kim SH, Lee MS, Joe SH, Jung IK, Kim L (2008) Possible association between the $-2548 \mathrm{~A} / \mathrm{G}$ polymorphism of the leptin gene and olanzapine-induced weight gain. Prog Neuropsychopharmacol Biol Psychiatry 32:160-163. doi:10.1016/j.pnpbp. 2007.08.002

Kroeze WK, Hufeisen SJ, Popadak BA, Renock SM, Steinberg S, Ernsberger P, Jayathilake K, Meltzer HY, Roth BL (2003) H1histamine receptor affinity predicts short-term weight gain for typical and atypical antipsychotic drugs. Neuropsychopharmacology 28:519-526

Leslie DL, Rosenheck RA (2004) Incidence of newly diagnosed diabetes attributable to atypical antipsychotic medications. Am J Psychiatr 161:1709-1711. doi:10.1176/appi.ajp. 161.9.1709 
Lieberman JA, Stroup TS, McEvoy JP, Swartz MS, Rosenheck RA, Perkins DO, Keefe RS, Davis SM, Davis CE, Lebowitz BD, Severe J, Hsiao JK, Clinical Antipsychotic of Intervention Effectiveness (CATIE) Investigators (2005) Effectiveness of antipsychotic drugs in patients with chronic schizophrenia. N Engl J Med 353:1209-1223. doi:10.1056/NEJMoa051688

Masaki T, Yoshimatsu H, Chiba S, Watanabe T, Sakata T (2001) Targeted disruption of histamine H1-receptor attenuates regulatory effects of leptin on feeding, adiposity, and UCP family in mice. Diabetes 50:385-391

Masaki T, Chiba S, Yasuda T, Noguchi H, Kakuma T, Watanabe T, Sakata T, Yoshimatsu H (2004) Involvement of hypothalamic histamine $\mathrm{H} 1$ receptor in the regulation of feeding rhythm and obesity. Diabetes 53:2250-2260

Matsui-Sakata A, Ohtani H, Sawada Y (2005) Receptor occupancybased analysis of the contributions of various receptors to antipsychotics-induced weight gain and diabetes mellitus. Drug Metab Pharmacokinet 20:368-378

Melkersson KI, Hulting AL, Brismar KE (2000) Elevated levels of insulin, leptin, and blood lipids in olanzapine-treated patients with schizophrenia or related psychoses. J Clin Psychiatr 61:742-749

Miller DD, Ellingrod VL, Holman TL, Buckley PF, Arndt S (2005a) Clozapine-induced weight gain associated with the 5HT2C receptor $-759 \mathrm{C} / \mathrm{T}$ polymorphism. Am J Med Genet B Neuropsychiatr Genet 133B:97-100

Miller EA, Leslie DL, Rosenheck RA (2005b) Incidence of new-onset diabetes mellitus among patients receiving atypical neuroleptics in the treatment of mental illness: evidence from a privately insured population. J Nerv Ment Dis 193:387-395

Mulder H, Franke B, van der Beek AA, Arends J, Wilmink FW, Scheffer H, Egberts AC (2007a) The association between HTR2C gene polymorphisms and the metabolic syndrome in patients with schizophrenia. J Clin Psychopharmacol 27:338-343

Mulder H, Franke B, van der Beek AA, Arends J, Wilmink FW, Egberts AC, Scheffer H (2007b) The association between HTR2C polymorphisms and obesity in psychiatric patients using antipsychotics: a cross-sectional study. Pharmacogenomics J 7:318-324. doi:10.1038/sj.tpj.6500422

Mulder H, Cohen D, Scheffer H, Gispen-de WC, Arends J, Wilmink FW, Franke B, Egberts AC (2009) HTR2C gene polymorphisms and the metabolic syndrome in patients with schizophrenia: a replication study. J Clin Psychopharmacol 29:16-20

Nasrallah HA (2006) Metabolic findings from the CATIE trial and their relation to tolerability. CNS Spectr 11:32-39

Nasrallah HA (2008) Atypical antipsychotic-induced metabolic side effects: insights from receptor-binding profiles. Mol Psychiatr 13:27-35

Newcomer JW (2005) Second-generation (atypical) antipsychotics and metabolic effects: a comprehensive literature review. CNS Drugs 19(Suppl 1):1-93

Parsons B, Allison DB, Loebel A, Williams K, Giller E, Romano S, Siu C (2009) Weight effects associated with antipsychotics: a comprehensive database analysis. Schizophr Res 110:103-110

Reynolds GP, Kirk SL (2010) Metabolic side effects of antipsychotic drug treatment-pharmacological mechanisms. Pharmacol Ther 125:169-179. doi:10.1016/j.pharmthera.2009.10.010

Reynolds GP, Zhang Z, Zhang X (2003) Polymorphism of the promoter region of the serotonin 5-HT(2 C) receptor gene and clozapine-induced weight gain. Am J Psychiatr 160:677-679
Risselada AJ, Vehof $\mathrm{J}$, Bruggeman R, Wilffert $\mathrm{B}$, Cohen $\mathrm{D}, \mathrm{Al}$ Hadithy AF, Arends J, Mulder H (2010) Association between HTR2C gene polymorphisms and the metabolic syndrome in patients using antipsychotics: a replication study. Pharmacogenomics J. doi:10.1038/tpj.2010.66

Roth BL, Sheffler DJ, Kroeze WK (2004) Magic shotguns versus magic bullets: selectively non-selective drugs for mood disorders and schizophrenia. Nat Rev Drug Discov 3:353359

Sakata T, Ookuma K, Fukagawa K, Fujimoto K, Yoshimatsu H, Shiraishi T, Wada H (1988) Blockade of the histamine H1receptor in the rat ventromedial hypothalamus and feeding elicitation. Brain Res 441:403-407

Sakata T, Kang M, Kurokawa M, Yoshimatsu H (1995) Hypothalamic neuronal histamine modulates adaptive behavior and thermogenesis in response to endogenous pyrogen. Obes Res 3(Suppl 5):707S-712S

Silvestre JS, Prous J (2005) Research on adverse drug events. I. Muscarinic M3 receptor binding affinity could predict the risk of antipsychotics to induce type 2 diabetes. Methods Find Exp Clin Pharmacol 27:289-304

Stephens M, Donnelly P (2003) A comparison of bayesian methods for haplotype reconstruction from population genotype data. Am J Hum Genet 73:1162-1169. doi:10.1086/379378

Stephens M, Smith NJ, Donnelly P (2001) A new statistical method for haplotype reconstruction from population data. Am J Hum Genet 68:978-989. doi:10.1086/319501

Swan C, Richards SA, Duroudier NP, Sayers I, Hall IP (2006) Alternative promoter use and splice variation in the human histamine H1 receptor gene. Am J Respir Cell Mol Biol 35:118 126. doi:10.1165/rcmb.2005-0408OC

Templeman LA, Reynolds GP, Arranz B, San L (2005) Polymorphisms of the 5-HT2C receptor and leptin genes are associated with antipsychotic drug-induced weight gain in Caucasian subjects with a first-episode psychosis. Pharmacogenet Genomics 15:195-200

Wirshing DA, Wirshing WC, Kysar L, Berisford MA, Goldstein D, Pashdag J, Mintz J, Marder SR (1999) Novel antipsychotics: comparison of weight gain liabilities. J Clin Psychiatr 60:358363

Yevtushenko OO, Cooper SJ, O'Neill R, Doherty JK, Woodside JV, Reynolds GP (2008) Influence of 5-HT2C receptor and leptin gene polymorphisms, smoking and drug treatment on metabolic disturbances in patients with schizophrenia. $\mathrm{Br} \mathrm{J}$ Psychiatr 192:424-428. doi:10.1192/bjp.bp. 107.041723

Zaykin DV, Westfall PH, Young SS, Karnoub MA, Wagner MJ, Ehm MG (2002) Testing association of statistically inferred haplotypes with discrete and continuous traits in samples of unrelated individuals. Hum Hered 53:79-91

Zhang XY, Tan YL, Zhou DF, Haile CN, Cao LY, Xu Q, Shen Y, Kosten TA, Kosten TR (2007) Association of clozapineinduced weight gain with a polymorphism in the leptin promoter region in patients with chronic schizophrenia in a Chinese population. J Clin Psychopharmacol 27:246-251. doi:10.1097/jcp. 0b013e3180582412

Zimmermann U, Kraus T, Himmerich H, Schuld A, Pollmacher T (2003) Epidemiology, implications and mechanisms underlying drug-induced weight gain in psychiatric patients. J Psychiatr Res $37: 193-220$ 